\title{
COMMUNICATION MANAGEMENT TO INCREASE THE ATTRACTIVENESS AND PROFIT OF FITNESS CENTERS
}

\author{
Mirjana Nedovic ${ }^{1}$
}

\begin{abstract}
Nowadays, people are increasingly aware of the importance of a healthy lifestyle, which includes proper nutrition and engaging in sports activities. Sports and physical activity play an important role in all aspects of human life because they improve the quality of life and have positive effects on both mental and physical health. Anyone who is engaged in any sports activities reduces the risk of illness and has a more positive attitude towards life. Therefore, the existence of a fitness center is justified, and there is a growing interest in programs which can positively impact on a person in all aspects of their physical, mental, and social life. The purpose and the aim of this study is to find the most convenient way of communication of a fitness center with target groups of potential future clients. Current members' preferences regarding the quality of training and possible improvements and means of advertising, were determined through a questionnaire along with how much they are willing to pay for the provided services. The analysis of the results pointed out the best direction to follow in the fitness center business to help to guide development, and ensure the satisfaction of present and prospective members. It was concluded that fitness centers underutilized the marketing activities needed to promote their activities and cement their position in the market.
\end{abstract}

JEL Classification Numbers: H25, M89, I01; DOI: http://dx.doi.org/10.12955/cbup.v5.946

Keywords: attractions of studio sport, fitness, sales

\section{Introduction}

The role of marketing in sport is extremely important since without marketing as a characteristic feature of the modern way of thinking, it is not possible to push a company or any sports facility in the direction of a successful and profitable business.

Different authors provide different concepts of fitness. For example, in the dictionary of Vladimir Anić, fitness is described as a colloquial term meaning "various exercises to be performed in special centers for maintaining physical fitness" (Anić, 2004).

Certain cities in the Republic of Croatia, with the support of city authorities (Osijek and Zagreb), are converting parts of the city to fitness parks available to anyone who wishes to take care of their body and health. This points to the population's growing awareness of the importance of a healthy lifestyle, wherein exercise becomes a lifestyle, not a useless effort. It is precisely this way of thinking and the interest of the population, which affected the opening of a large number of fitness or sports centers visited by people of all age groups, from adolescents to pensioners. Since a large number of fitness centers opened in recent years, greater efforts are needed to attract potential members. Therefore, the use of market surveys becomes a basis for designing the services or products that are in demand.

According to Sullivan (2004), the main objective of sports marketing is to meet the real need of customers for sports products and services which offer greater benefits than that of the competitors, and simultaneously achieve the highest sustainable profit. Additionally, Novak (2006) believes that: "Sports marketing is a management process, based on the social marketing concept in which individuals and society as a whole, by specific access and use of the business of sports, obtain what they need and want, with the help of an important set of activities which enable the market sharing of primarily sports products and services".

Sports marketing is becoming an important tool of communication with the market through which one can learn the wishes and needs of stakeholders, and thus design the products and services required.

This study presents fitness centers' marketing activities relevant to the market. A survey has been carried out with the aim of learning the fitness center users' opinions on the provided quality, as well as information such as which marketing activities they think can encourage users to reach for their service, and thus improve the sales over an extended period.

\section{Fitness Centre Marketing Activities and Goal Setting}

Marketing activities attract potential customers, seeking to have their needs met, thus the aim is to make them satisfied with the provided service. Before designing the most appropriate tool for communication

\footnotetext{
${ }^{1}$ College of Applied Sciences “Lavoslav Ruzička” in Vukovar, mnedovic@vevu.hr
} 
with prospective customers, it is necessary to conduct an analysis of the current situation and learn fitness center wants, i.e. what it wishes to become in the future.

For the objectives to be useful, there are several key criteria that must be followed, therefore we can talk about SMART goals (Lan \& Ping, 2010):

- Specific - the objective must relate to a specific part of the activities

- Measurable - the objective must be susceptible to measuring

- Actionable - the objective must be able to be put into action

- Realistic - the objective must be achievable and appropriate to the market situation

- Time framed - the objective must have a completion date

Considering the set objectives, the fitness center goals can be defined more precisely:

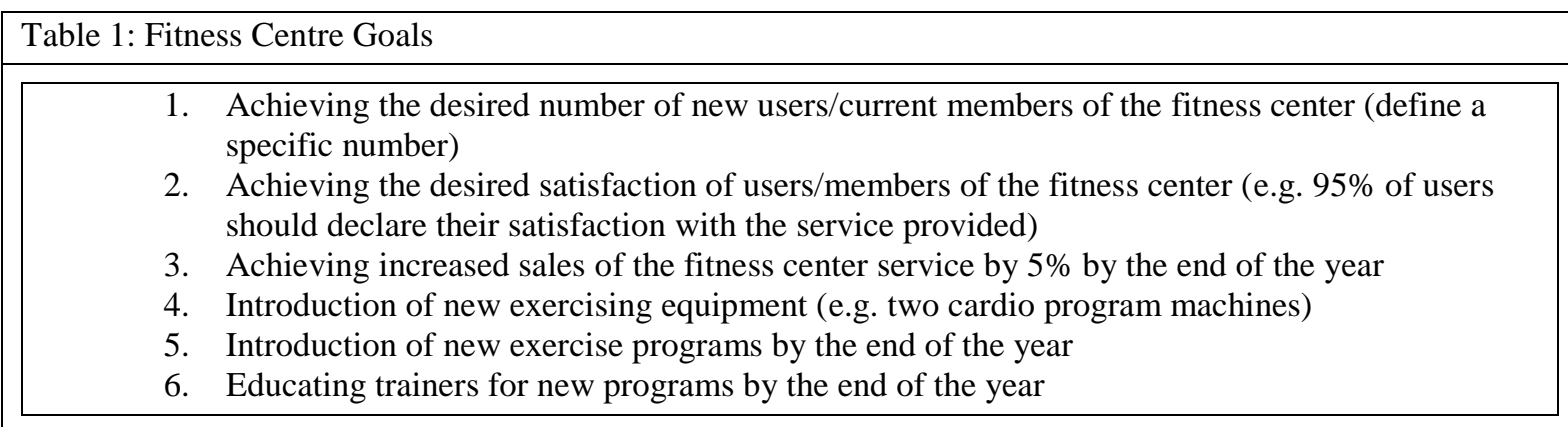

Source: Author

Table No. 1 lists the goals that should be defined in order to improve business. Only clearly defined goals can help the business to move forward and develop. Well defined objectives include effective management of the fitness center and contribute to its development, therefore they present a prerequisite for the survival in the market, provided that they really are defined so as to be attainable and achievable.

Advertising, licensing and promotional activities have been increasing steadily in the market, therefore it is necessary to invest additional efforts in finding new users and retain the existing ones who can, under the influence of competitors' advertising, change fitness centers, current coach and reach out for the competition. Fitness center management must therefore make an extraordinary effort to retain the existing members by doing everything to fully satisfy them. This implies deliberate management and business planning. Thus marketing becomes a tool in the market with the help of which one can fight off competitors and secure the customers' loyalty. However, it should be noted that regardless of the marketing activities, perhaps even aggressive ones, the users will not use fitness center services if they do not feature a certain level of quality of training and customer care provided by the staff.

Therefore, loyal customers are less likely to be lured by a competitor, regardless of the competitor's marketing efforts. Similarly, customers who are dissatisfied with a product are not likely to continue purchasing that product (Gray \& Wert-Gray, 2012). Consequently, it is essential to learn more about the effects of various promotion techniques for better marketing planning (Irwin, Sutton \& McCarthy, 2002).

A challenge with advertising communications is to fully understand beliefs driving people's reaction toward advertising. Successful implementation of sports communication needs a better understanding of the beliefs composing reactions toward advertising of sports (Aminiroshana, Sharifianb, \& Siyadata, 2014).

\section{Research}

In March 2017, we conducted a survey for the collection of fitness centers users' opinions. The survey allowed us to learn how marketing activities of the fitness center are received by the target group. We surveyed 40 participants. The questionnaire consisted of 8 questions divided into three segments:

1. Analysis of the basic set

2. Consumer perceptions about services

3. Service pricing level deemed acceptable by the respondents

Close-ended questions were used while creating this survey. The participants were surveyed based on whether they agreed or disagreed with certain claims by using a dichotomous scale (Yes or No). 
Also, certain questions were multiple-choice and the participants circled the response which fit them best. The data gathered were grouped, graphically displayed, and analyzed by conventional methods of descriptive statistics using the Microsoft Excel program. Table 2 lists the questions used during the survey:

\begin{tabular}{||cl||}
\hline \multicolumn{2}{|c||}{ Table 2: List of survey questions } \\
\hline 1. & Which of the marketing activities would most likely convince you to go to a fitness center? \\
\hline 2. & $\begin{array}{l}\text { Do you think that a fitness center should employ a person assigned only to marketing and } \\
\text { promotion? }\end{array}$ \\
\hline 3. & Do you think that fitness centers in your area are advertised strongly enough? \\
\hline 4. & What would motive you to go to a fitness center? \\
\hline 5. & In what way is visiting fitness centers useful for health? \\
\hline 7. & $\begin{array}{l}\text { Would the guarantee of a coach directing you to your desired result (following compliance with } \\
\text { the instructions) motivate you to go to a fitness center? }\end{array}$ \\
\hline 8. & How much would you be willing to pay on a monthly basis for a group exercise class/ training? \\
\hline Source: Author \\
\hline
\end{tabular}

\section{Results and Discussion}

After conducting the survey, we started processing the resulting data by using statistical tables, and the results were shown graphically. The research involved a total of 40 subjects $(n=40)$ from VukovarSrijem County. Of the total number of respondents, $62 \%$ were female and $36 \%$ male (Figure 1).

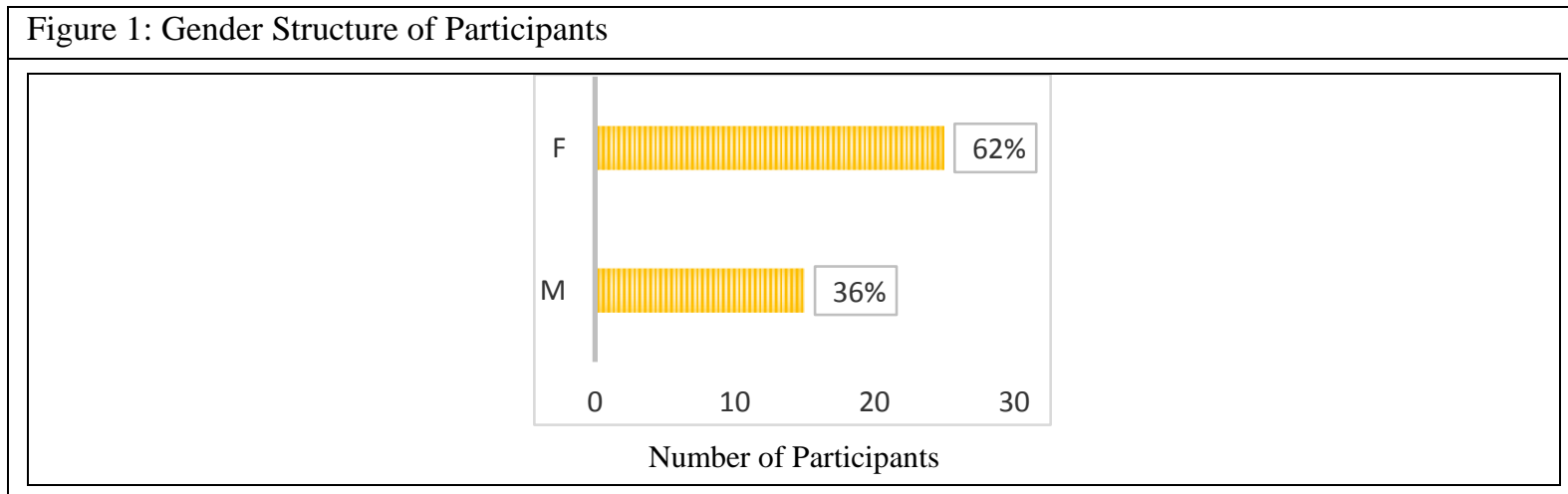

Source: Author

Figure 2: Fitness center advertising preferences

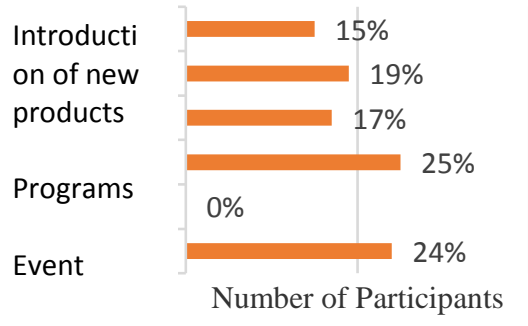

Source: Author

Considering the fitness center advertising preferences, the participants believe that the most appropriate way of advertising is through TV and radio, 25\%; closely followed by advertising on the Internet $24 \%$ (Figure 2).

$70 \%$ of participants believe that a fitness center should employ a person assigned only to marketing and promotion because they think in this way the public can obtain more detailed information about the 
services provided and the events taking place, while $30 \%$ of respondents believe that the employment of a person assigned to marketing activities only is not necessary (Figure 3).

Figure 3: Do you think that a fitness center should employ a person assigned only to marketing and promotion?

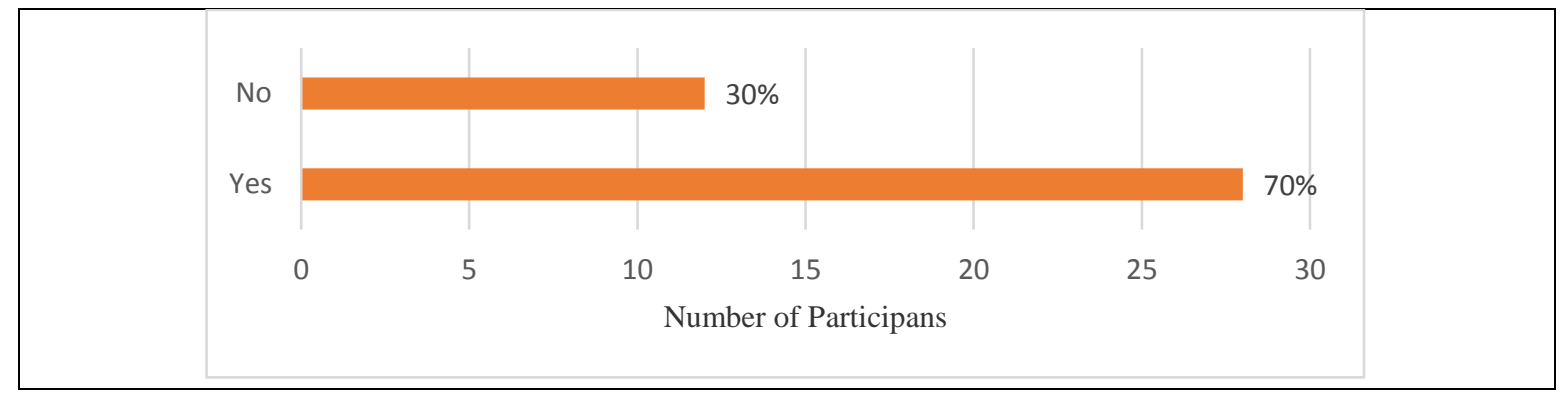

Source: Author

The majority of participants believe that fitness centers are not advertised strongly enough (75\%), while $25 \%$ of participants believe that the advertising is sufficient (Figure 4).

\begin{tabular}{|l|l|l|l|l|l|}
\hline Figure 4: Do you think that fitness centers in your area are advertised strongly enough? \\
\hline
\end{tabular}

According to data shown in the graph below (Figure 5), it is apparent that the biggest group of participants (38\%) is willing to spend $200 \mathrm{HRK}$ on a monthly basis for a fitness center program. $30 \%$ are willing to spend $300 \mathrm{HRK}, 10 \%$ can spend $400 \mathrm{HRK}$ or more, and 23\% would spend up to 100 HRK on a monthly basis.

Figure 5: How much would you be willing to pay on a monthly basis for a group/program training?

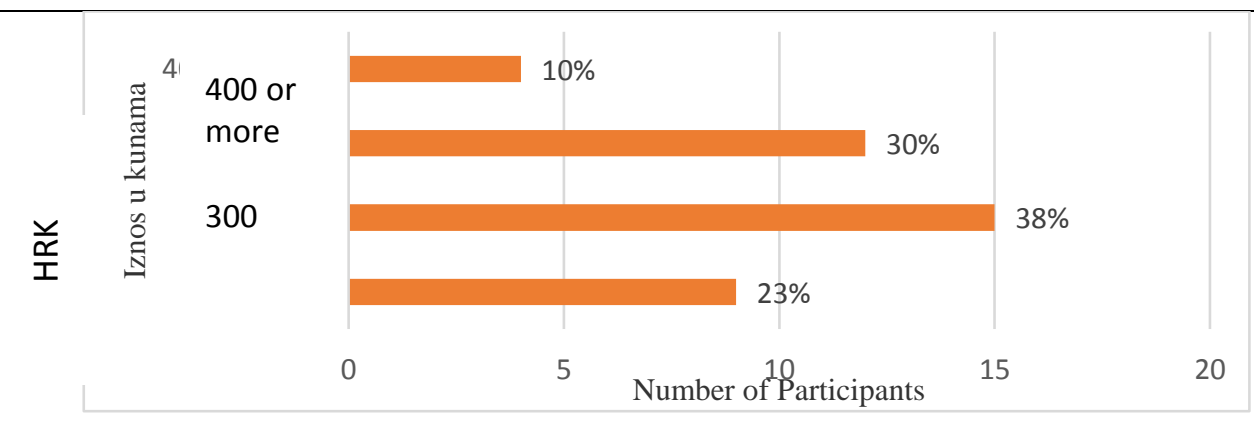

Source: Author

\section{Conclusion}

Based on the results presented, it can be concluded that the frequency of use of particular forms of market advertising (TV/Radio and advertising via the Internet) attract the greatest attention of future and the existing users fitness centers. Today information is readily available on the Internet and the presented 
advertising methods provide information to all interested parties in a quick way. It is indisputable that the successful development and market performance of a fitness center is dependent on employment of appropriate marketing activities along with offering quality service, and setting adequate prices. Highquality marketing activities will increase the attractiveness of fitness centers, improve business and sales, and positively affect the number of its clients. Furthermore, through research it can be concluded that fitness centers inadequately implement marketing activities in and presenting and promoting their services, and that this is also noticed by the existing customers. In fact, clients do not have sufficient information on the activities carried out and believe that the employment oof marketing specialists would positively affect the attractiveness of fitness centers and increase sales. Following all of the above, it is suggested for the fitness centers to employ a person for carrying out marketing activities, developing marketing programs, intensive advertising, and ensuring continuous customer satisfaction.

\section{References}

Aminiroshana, Z., Sharifianb, E., \& Siyadata, S. (4. 5 2014). Sport promotion and sales management. Management Science Letters , str. 1177-1180.

Anić, V. (2004). Rječnik hrvatskoga jezika. Zagreb: Novi Liber.

Gray, G., \& Wert-Gray, S. (2012). Customer retention in sports organization marketing:examining the impact of team identification and satisfaction. International Journal of Consumer Studies, str. 275-281.

Irwin, R., Sutton, W., \& McCarthy, L. (2002). Sport promotion and sales management. Human Kinetics.

Lan, H., \& Ping, C. (2010). Upravljanje i etika u sportu. U Sportski menadžment (str. 140-141). Zagreb: Mate d.o.o.

Novak, I. (2006). Sportski marketing. Zagreb: Maling.

Sullivan, M. (2004). Sportski menadžment. Zagreb: Mate d.o.o. 